Article

\title{
Experimental Performance of a Solar Air Collector with a Perforated Back Plate in New Zealand
}

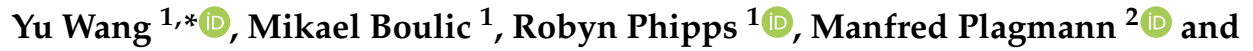 \\ Chris Cunningham ${ }^{3}$ (D) \\ 1 School of Built Environment, Massey University, Auckland 0632, New Zealand; \\ M.Boulic@massey.ac.nz (M.B.); R.A.Phipps@massey.ac.nz (R.P.) \\ 2 BRANZ, Porirua 5381, New Zealand; Manfred.Plagmann@branz.co.nz \\ 3 Research Centre for Maori Health and Development, Massey University, Wellington 6021, New Zealand; \\ cwcunningham@xtra.co.nz \\ * Correspondence: Y.Wang9@massey.ac.nz; Tel.: +64-9-213-6133
}

Received: 2 January 2020; Accepted: 12 March 2020; Published: 18 March 2020

check for updates

\begin{abstract}
This study investigates the thermal efficiency of a solar air heater (SAH), when it was mounted on a custom-made support frame, and was operated under different air mass flow rate. This SAH is composed of a transparent polycarbonate cover plate, a felt absorber layer, a perforated aluminium back plate and an aluminium frame. The ambient inlet air of this SAH is heated as it passes through the perforated back plate and over the felt absorber layer. The heated air is blown out through the outlet. Studies of SAHs with a similar design to this SAH were not found in the literature. The experiment was carried out at Massey University, Auckland campus, NZ ( $\left.36.7^{\circ} \mathrm{S}, 174.7^{\circ} \mathrm{E}\right)$. The global horizontal solar irradiance, the ambient temperature and the wind speed were recorded using an on-site weather station. Temperature and velocity of the air at the outlet were measured using a hot wire anemometer. During the experiment, the air mass flow rate was between $0.022 \pm$ $0.001 \mathrm{~kg} / \mathrm{s}$ and $0.056 \pm 0.005 \mathrm{~kg} / \mathrm{s}$. Results showed that when the SAH was operated at the airflow between $0.0054 \mathrm{~kg} / \mathrm{s}$ and $0.0058 \mathrm{~kg} / \mathrm{s}$, the inlet air temperature and the wind speed (between 0 and $6.0 \mathrm{~m} / \mathrm{s}$ ) did not impact the temperature difference between the outlet air and the inlet air. The thermal efficiency of the SAH increased from $34 \pm 5 \%$ at the airflow between $0.021 \mathrm{~kg} / \mathrm{s}$ and $0.023 \mathrm{~kg} / \mathrm{s}$, to $47 \pm$ $6 \%$ at the airflow ranging from $0.032 \mathrm{~kg} / \mathrm{s}$ to $0.038 \mathrm{~kg} / \mathrm{s}$, to $71 \pm 4 \%$ at the airflow of $0.056 \pm 0.005 \mathrm{~kg} / \mathrm{s}$. The maximum thermal efficiency of $75 \%$ was obtained at the airflow of $0.057 \mathrm{~kg} / \mathrm{s}$. The effective efficiency of the SAH was $32 \pm 5 \%$ at the airflow between $0.021 \mathrm{~kg} / \mathrm{s}$ and $0.023 \mathrm{~kg} / \mathrm{s}, 42 \pm 6 \%$ at the airflow ranging from $0.032 \mathrm{~kg} / \mathrm{s}$ to $0.038 \mathrm{~kg} / \mathrm{s}$, and $46 \pm 11 \%$ at the airflow of $0.056 \pm 0.005 \mathrm{~kg} / \mathrm{s}$.
\end{abstract}

Keywords: solar air heating; porous absorber layer; perforated back plate; thermal efficiency

\section{Introduction}

The thermal efficiency of a solar air heater (SAH) is defined as the ratio of the energy converted to the solar energy incident on the SAH collector panel [1]. The design and the operation conditions are the main factors that influence the efficiency of a SAH. The main components for the design include the cover, flow types and absorber layer. Operation conditions include the air mass flow rate and the weather conditions (solar radiation, ambient temperature and wind speed).

Several research projects have focused on modifying the configurations of the SAH to increase the heat transfer performances. These modifications include changing shapes and materials of the absorber layer [2-7], increasing the air channel turbulence [8-11], modifying the flow type [12-14] and the cover plate [15]. Table 1 shows the efficiencies of several types of SAH, when they were operated at different air mass flow rate. 
Table 1. Efficiencies of several types of solar air heater operated at different air mass flow rate.

\begin{tabular}{|c|c|c|c|c|c|c|}
\hline Study & $\begin{array}{c}\text { Air Mass } \\
\text { Flow Rate } \\
(\mathrm{kg} / \mathrm{s})\end{array}$ & Cover & Flow Type & Absorber Layer & Efficiency (\%) & Reference \\
\hline 1 & $\begin{array}{l}0.010 \mathrm{~kg} / \mathrm{s} ; \\
0.020 \mathrm{~kg} / \mathrm{s} ; \\
0.030 \mathrm{~kg} / \mathrm{s} ; \\
0.040 \mathrm{~kg} / \mathrm{s} ; \\
0.050 \mathrm{~kg} / \mathrm{s} \\
0.060 \mathrm{~kg} / \mathrm{s}\end{array}$ & $\begin{array}{l}\text { Double } \\
\text { glazed }\end{array}$ & $\begin{array}{l}\text { Double parallel pass; } \\
\text { Placing the absorber } \\
\text { plate in the middle of } \\
\text { the air channel } \\
\text { forming the equal } \\
\text { upper and lower flow } \\
\text { channel. }\end{array}$ & $\begin{array}{l}\text { Type 1: flat plate; } \\
\text { Type 2: longitudinal } \\
\text { fins below and above } \\
\text { the absorber layer; } \\
\text { Type 3: V-corrugated } \\
\text { shaped absorber layer. }\end{array}$ & $\begin{array}{c}\text { Type } 3 \text { was } 11 \% \text { to } 14 \% \\
\text { more efficiency than } \\
\text { Type } 1 ; \\
\text { Type } 3 \text { was } 9 \% \text { to } 12 \% \\
\text { more efficient than } \\
\text { Type } 2 ; \\
\text { Maximum efficiencies } \\
\text { at air mass flow rate of } \\
0.060 \mathrm{~kg} / \mathrm{s} \text { : } \\
\text { Type } 1: 58 \% ; \\
\text { Type } 2: 56 \% ; \\
\text { Type } 3: 65 \% .\end{array}$ & {$[15,16]$} \\
\hline 3 & $\begin{array}{l}0.012 \mathrm{~kg} / \mathrm{s} \\
0.016 \mathrm{~kg} / \mathrm{s}\end{array}$ & $\begin{array}{l}\text { Single } \\
\text { glazed }\end{array}$ & Single pass & $\begin{array}{c}\text { Type 1: galvanized iron } \\
\text { sheet with } 0.5 \text { mm thick } \\
\text { black chrome selective } \\
\text { coating, without fins; } \\
\text { Type 2: five } \\
\text { longitudinal and hollow } \\
\text { semi-cylindrical fins } \\
\text { located below the } \\
\text { absorber layer }\end{array}$ & $\begin{array}{l}\text { Maximum efficiencies } \\
\text { at air mass flow rate of } \\
0.012 \mathrm{~kg} / \mathrm{s} \text { and } 0.016 \\
\mathrm{~kg} / \mathrm{s}: \text { Type } 1: 35 \% \text { and } \\
44 \% \text { respectively; } \\
\text { Type } 2: 40 \% \text { and } 52 \% \\
\text { respectively. }\end{array}$ & [9] \\
\hline 5 & $\begin{array}{c}0.012 \mathrm{~kg} / \mathrm{s} \text { to } \\
0.038 \mathrm{~kg} / \mathrm{s}\end{array}$ & $\begin{array}{l}\text { Double } \\
\text { glazed; }\end{array}$ & $\begin{array}{l}\text { Type 1: Single pass } \\
\text { through wire mesh; } \\
\text { Type 2: Double } \\
\text { counter pass through } \\
\text { wire mesh. }\end{array}$ & $\begin{array}{l}\text { A steel wire mesh with } \\
\text { fins. }\end{array}$ & $\begin{array}{c}\text { Maximum efficiencies } \\
\text { at air mass flow rate of } \\
0.038 \mathrm{~kg} / \mathrm{s}: \\
\text { Type } 1: 60 \% \\
\text { Type } 2: 64 \% .\end{array}$ & [19] \\
\hline 6 & $\begin{array}{c}0.012 \mathrm{~kg} / \mathrm{s} \text { to } \\
0.042 \mathrm{~kg} / \mathrm{s}\end{array}$ & $\begin{array}{l}\text { Double } \\
\text { glazed; }\end{array}$ & $\begin{array}{l}\text { Double pass; } \\
\text { First flow channel was } \\
\text { formed by the two } \\
\text { glass layers; } \\
\text { Second flow channel } \\
\text { was formed by the } \\
\text { lower glass cover and } \\
\text { the absorber layer. }\end{array}$ & $\begin{array}{l}\text { Wire mesh layers } \\
\text { between the fins; } \\
\text { Type 1: With } 2 \text { fins } \\
\text { attached; } \\
\text { Type 2: With } 4 \text { fins } \\
\text { attached; } \\
\text { Type 3: With } 6 \text { fins } \\
\text { attached. }\end{array}$ & $\begin{array}{c}\text { Maximum efficiencies } \\
\text { at air mass flow rate of } \\
0.042 \mathrm{~kg} / \mathrm{s}: \\
\text { Type } 1: 75 \% \\
\text { Type } 2: 82 \% \text {; } \\
\text { Type 3: } 86 \% .\end{array}$ & {$[20]$} \\
\hline
\end{tabular}

Among all the reported SAH in Table 1, efficiencies ranged from $35 \%$ to $86 \%$ when they were operated at the mass flow rate from $0.010 \mathrm{~kg} / \mathrm{s}$ to $0.060 \mathrm{~kg} / \mathrm{s}$. Study 6 Type 3 SAH showed the maximum efficiency of $86 \%$ at the air mass flow rate of $0.042 \mathrm{~kg} / \mathrm{s}$. 
Study 1 (Table 1) to Study 4 (Table 1) showed artificially roughening the absorber layer can increase the efficiency of the SAH $[9,15-18]$. Study $1[15,16]$ showed that the double pass SAH with V corrugated shape absorber layer was from $11 \%$ to $14 \%$ and from $9 \%$ to $12 \%$ more efficient than the double pass SAH with flat and finned absorber layer respectively. Karim and Hawlader [17] (Table 1, Study 2) found a single pass SAH with finned absorber layer was $4 \%$ more efficient than the flat plate $\mathrm{SAH}$. The single pass SAH with V corrugated shape absorber layer was $10 \%$ more efficient than the flat plate SAH. Chabane, Moummi and Benramache [9] (Table 1, Study 3) reported that the maximum efficiency of a single pass SAH with fins below the absorber layer was $5 \%$ and $8 \%$ more efficient than the one without fins, at the air mass flow rates of $0.012 \mathrm{~kg} / \mathrm{s}$ and $0.016 \mathrm{~kg} / \mathrm{s}$ respectively. Ozgen, Esen and Esen [18] (Table 1, Study 4) compared a parallel double flow SAH with zigzag arranged aluminium cans on the absorber layer, orderly arranged aluminium cans on the absorber layer, and the smooth absorber layer at the air mass flow rate of $0.030 \mathrm{~kg} / \mathrm{s}$ and $0.050 \mathrm{~kg} / \mathrm{s}$. The maximum efficiency of $73 \%$ was found for the $\mathrm{SAH}$ with zigzag-arranged cans on absorber layer at the air mass flow rate of 0.050 $\mathrm{kg} / \mathrm{s}$. In short, artificially roughening the SAH absorber layer can increase the efficiency of the SAH.

Modifying the airflow type is another way to increase the heat transfer of the SAH [12-14]. Airflow types can be categorized as: (i) single flow (with only one flow channel over or under the absorber layer); (ii) double flows (double pass parallel flow or double pass counter flow); and (iii) air flow through a matrix absorber layer [13]. There are two ways to create the double flow. One is using the top glass cover and the bottom glass cover (double glazed SAH) forming the upper channel, with the lower glass cover and the absorber layer forming the lower channel. Another double flow SAH is designed by placing the absorber layer inside the air duct to form the double air passage around absorber layer. The maximum thermal efficiency was achieved by placing the absorber layer in the middle of the air channel, with the upper and lower channels of equal size [21]. Omojaro and Aldabbagh [19] (Table 1, Study 5) showed a $4 \%$ increase of the thermal efficiency when the SAH was modified from single flow to double flow. Karim and Hawlader [17] (Table 1, Study 2) reported a 13\%, 10\% and 7\% thermal efficiency increase for $\mathrm{V}$ corrugated shape, finned and flat plate absorber layer when changing the airflow type from single flow to double flow. Dhiman, Thakur and Chauhan [12] found that the thermal efficiency of a counter flow SAH was from $11 \%$ to $17 \%$ higher than the same SAH with parallel flow, when they were operated at the air mass flow rate from $0.012 \mathrm{~kg} / \mathrm{s}$ to $0.038 \mathrm{~kg} / \mathrm{s}$. In conclusion, modifying the airflow type can increase the thermal efficiency of a SAH.

The thermal performance of six types of SAH was investigated [19,20,22-24]. The first SAH had a steel wire mesh absorber layer [22], the second SAH had a steel wire mesh absorber layer and longitude fins attached [19]. The third one had a steel wire mesh absorber layer with transverse fins attached and 'S-shape' airflow (Table 1, Study 6) [20]. The forth one had a steel wire mesh absorber layer with transverse fins attached and '8-Shape' airflow [23]. The fifth one had a steel wire mesh absorber layer and a partially perforated cover [24]. The performance of these five SAHs was compared with a similar $\mathrm{SAH}$ without any modifications (the sixth type SAH).

The authors concluded that the SAH with the wire mesh absorber layer (matrix layer) was efficient, as air passing through the wire mesh absorber layer can maximize heat extraction [5]. The SAH with modified rough air channels performed better than the SAH with smooth air channel. The double-pass SAH was more efficient than the single pass SAH. For the double-pass SAH, the height of the upper channel negatively impacted on the thermal efficiency. The narrower the upper channel, the more efficient the SAH was. When the SAH was operated at air mass flow rate of $0.036 \mathrm{~kg} / \mathrm{s}$, thermal efficiencies were respectively $62 \%, 59 \%$ and $57 \%$ at the height of the upper channel of $30 \mathrm{~mm}, 50 \mathrm{~mm}$ and $70 \mathrm{~mm}$ [19]. The maximum thermal efficiency $(86 \%)$ was obtained from the third type SAH (the double-pass counter flow SAH with six transverse fins and 'S-shape' airflow channel) at the air mass flow rate of $0.042 \mathrm{~kg} / \mathrm{s}$ [20].

Our study aims to investigate the thermal efficiency of a SAH when it was operated at different air mass flow rate. The experiment was conducted under Auckland, NZ weather conditions. The thermal efficiency of this studied SAH is compared to some other SAHs reported in the introduction. 
This studied SAH has the inlet air coming from a perforated back plate and then passing through and over the absorber layer before it is ducted. Results for investigating thermal efficiency of such type SAH have not been reported in the literature yet.

The paper is organized as following: materials and methods for investigating thermal efficiency of the SAH are presented in Section 2, including the structure of this studied SAH; experiment setup, test procedure and the thermal efficiency calculation. Section 3 presents the experimental results. Section 4 concludes the finding along with the future research.

\section{Materials and Methods}

\subsection{Structure of the Studied Solar Air Heater}

Figure 1 shows the exploded view of the studied SAH.

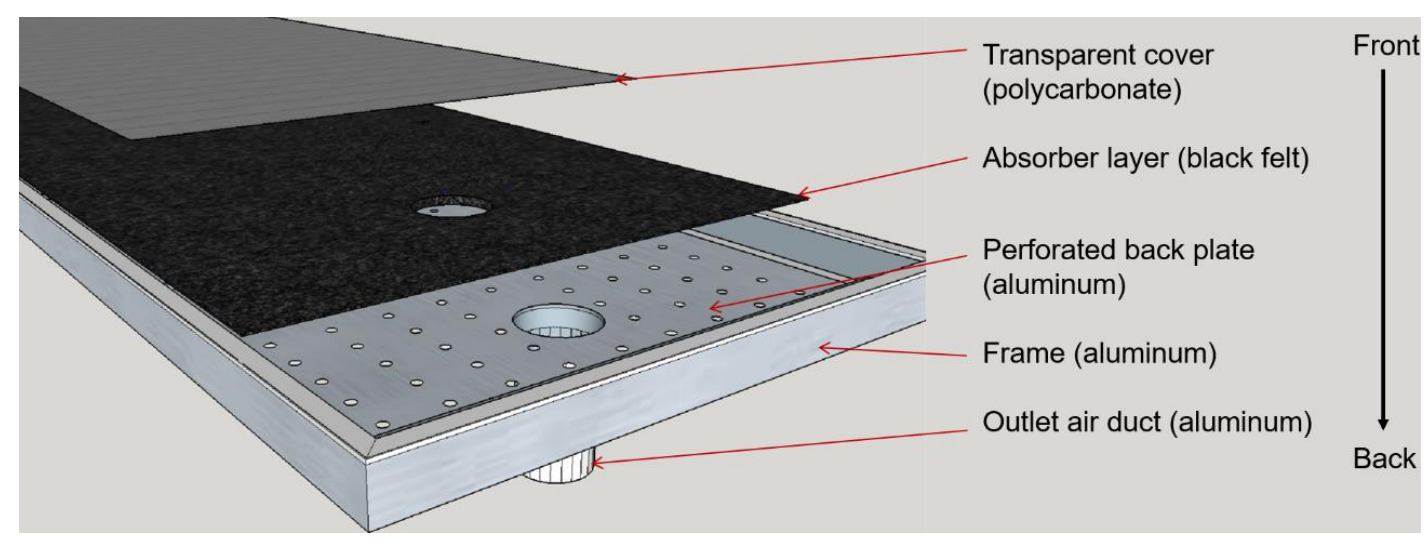

Figure 1. Exploded view of the studied solar air heater.

Figure 1 shows that this SAH, from the front to the back, is composed of a transparent cover (polycarbonate), an absorber layer (black felt), a perforated back plate (aluminium) and an aluminium frame. The diameter of the outlet air duct is $125 \mathrm{~mm}$. The diameter of the air inlet holes on the perforated back plate is $1.5 \mathrm{~mm}$. These holes are evenly distributed in a grid, spaced at $15 \mathrm{~mm}$ apart (approximately 4300 holes $/ \mathrm{m}^{2}$ ).

Figure 2 shows the schematic view of the studied SAH.

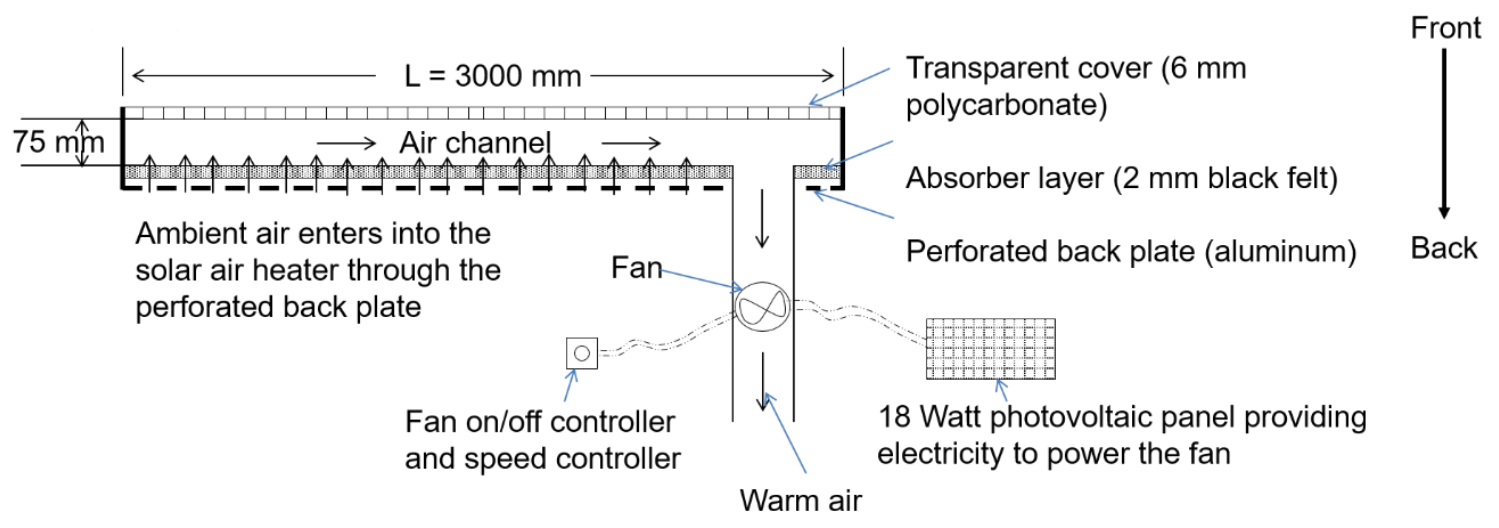

Figure 2. Schematic view of the studied solar air heater.

The length, width, and air channel depth of this SAH are $3000 \mathrm{~mm}, 1020 \mathrm{~mm}$ and $75 \mathrm{~mm}$ respectively. The collector gross area and the absorber layer effective area are both $3 \mathrm{~m}^{2}$. The SAH has a fan (power consumption: 5.1 Watt), a fan speed on/off controller (regulator) and an outlet duct. The fan is powered by an 18 Watt photovoltaic panel. The ambient air enters into the SAH through the 
perforated back plate. The heated air is pushed in the outlet duct by the fan. The velocity of the outlet air was controlled by the fan speed controller (regulator).

\subsection{Experiment Setup and Test Procedure}

During the experiment, the SAH was mounted on a custom-made galvanized metal frame. Figure 3 shows the setup of the experiment.

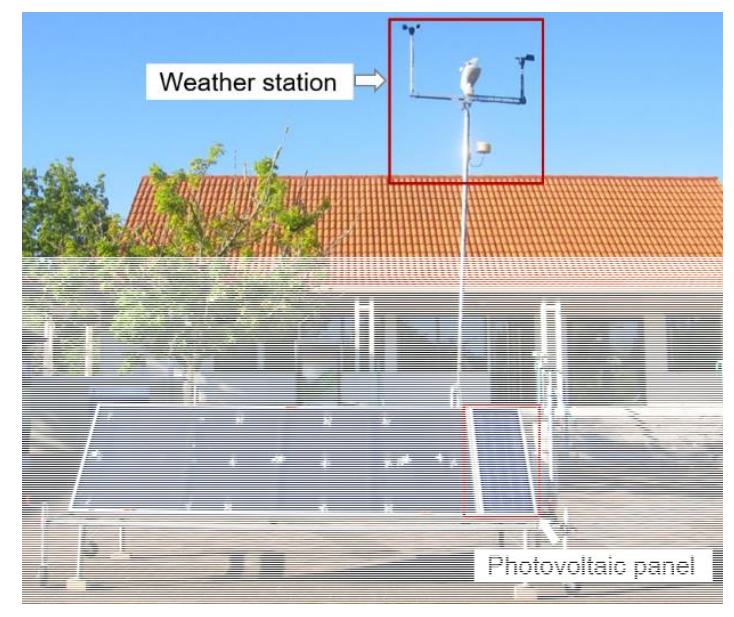

Figure 3. Setup of the experiment.

The SAH panel was $52^{\circ}$ off the horizontal surface (local latitude $37^{\circ}$ plus $15^{\circ}$ ). The panel faced due north (at the azimuth angle of $0^{\circ}$ ). The global horizontal solar irradiance, the ambient temperature and the wind speed were recorded by an onsite weather station (HP2000 Wi-Fi Weather Station, Fine Offset Electronics Co., Ltd., Shenzhen, China), as shown in Figure 3. The velocity and the temperature of the outlet air were monitored by a hot wire anemometer (AM4214SD, Lutron Electronic Enterprise Co. Ltd., Taipei City, Taiwan).

Table 2 shows the characteristics of the monitoring devices.

Table 2. The characteristics of the monitoring devices.

\begin{tabular}{cccc}
\hline Device & Monitored Parameters & Range & Accuracy \\
\hline HP2000 weather station & Solar irradiance $\left(\mathrm{W} / \mathrm{m}^{2}\right)$ & $0-3000 \mathrm{~W} / \mathrm{m}^{2}$ & $\pm 15 \%$ \\
\hline & Ambient air temperature $\left({ }^{\circ} \mathrm{C}\right)$ & $-30-65{ }^{\circ} \mathrm{C}$ & $\pm 1{ }^{\circ} \mathrm{C}$ \\
\hline $\begin{array}{c}\text { AM4214SD hot wire } \\
\text { anemometer }\end{array}$ & Wind speed $(\mathrm{m} / \mathrm{s})$ & $0-50 \mathrm{~m} / \mathrm{s}$ & $\begin{array}{c} \pm 1 \mathrm{~m} / \mathrm{s} \text { (wind speed }<5 \mathrm{~m} / \mathrm{s}) ; \\
\pm 10 \% \text { (wind speed }>5 \mathrm{~m} / \mathrm{s})\end{array}$ \\
\hline & Outlet air velocity $(\mathrm{m} / \mathrm{s})$ & $0.2-25 \mathrm{~m} / \mathrm{s}$ & $\pm 5 \%$ of reading \\
\hline
\end{tabular}

The experiment was carried out for 9 days at Massey University's Auckland campus, NZ $\left(36.7^{\circ} \mathrm{S}\right.$, $174.7^{\circ} \mathrm{E}$ ). The test began at $9 \mathrm{am}$ and ended at $4 \mathrm{pm}$ (New Zealand Daylight Time). On each day, the air was circulated through the panel for at least $10 \mathrm{~min}$ prior to commencing the measurement. During the test, the fan regulator was set at $50 \%$ maximum speed of the ventilator from Day 1 to Day 4 ; at $75 \%$ maximum speed of the ventilator from Day 5 to Day 8, and 100\% maximum speed of the ventilator on Day 9 . The $50 \%$ and $75 \%$ maximum speed of the ventilator were set to investigate the efficiency and the outlet air temperature rise (between the outlet air and inlet air) of this $\mathrm{SAH}$, when it was operated at different air mass flow rate. 


\subsection{Thermal Efficiency Calculation}

The thermal efficiency of the SAH was estimated based on Equation (1).

$$
\eta=\frac{\dot{m} C_{P}\left(T_{o}-T_{i}\right)}{A_{c} I_{T}}=\frac{\rho \vartheta A_{d} C_{P}\left(T_{o}-T_{i}\right)}{A_{c} T_{T}}
$$

where,

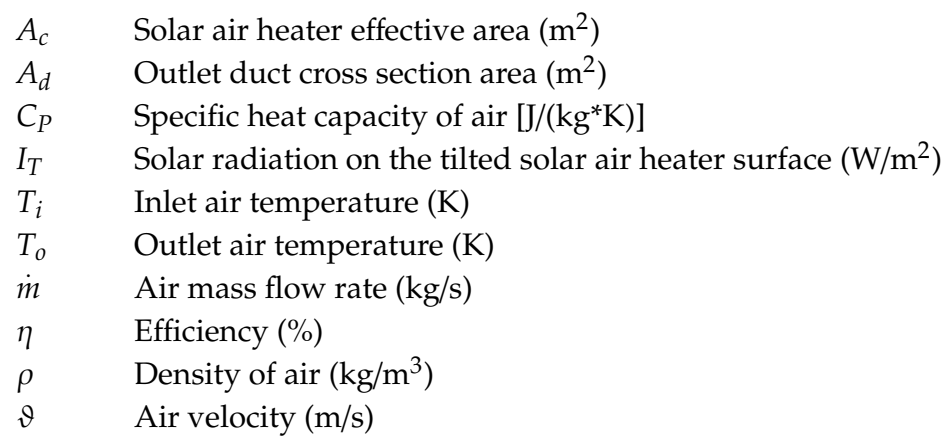

During the calculation, it was assumed that the monitored air velocity was the mean air velocity. The ambient air temperature was the inlet air temperature. Equation (1) shows that efficiency of the SAH depends on air mass flow rate and the parameter that temperature difference between outlet air and inlet air divide the solar radiation on the tilted solar collector surface, as air specific heat capacity and solar collector effective area were constant. The air density and the air specific heat capacity were set according to the air temperature, as shown in Table 3 [25].

Table 3. Air density and air specific heat capacity under different temperature; Source: [25].

\begin{tabular}{|c|c|c|c|}
\hline Air Temperature (K) & Air Density $\left(\mathrm{kg} / \mathrm{m}^{3}\right)$ & $\begin{array}{c}\text { Air specific Heat } \\
\text { Capacity }\left(\mathrm{J} /\left(\mathrm{kg}^{*} \mathrm{~K}\right)\right)\end{array}$ & $\begin{array}{l}\text { Air Dynamic Viscosity } \\
\quad \times 10^{-5}\left(\mathrm{~kg} /\left(\mathrm{m}^{*} \mathrm{~s}\right)\right)\end{array}$ \\
\hline$[273.15,283.15]$ & 1.269 & 1006 & 1.748 \\
\hline$[283.15,293.15]$ & 1.225 & 1007 & 1.797 \\
\hline$[293.15,303.15]$ & 1.184 & 1007 & 1.844 \\
\hline$[303.15,313.15]$ & 1.145 & 1007 & 1.892 \\
\hline$[313.15,323.15]$ & 1.109 & 1007 & 1.938 \\
\hline$[323.15,333.15]$ & 1.076 & 1007 & 1.984 \\
\hline$[333.15,343.15]$ & 1.044 & 1007 & 2.029 \\
\hline
\end{tabular}

The solar radiation incident on the absorber layer was calculated using the computer program solaR [26]. The Spencer model [27] was chose to calculate the declination angle and the extra-terrestrial radiation incident on the plane. The Boland-Ridley-Lauret model was used to calculate the horizontal diffuse solar radiation based on the measured global horizontal solar radiation [28,29]. The Boland-Ridley-Lauret model performed well in both North and South Hemispheres [28]. The Hay and McKay model was used to estimate the diffuse radiation on the inclined absorber plate [30]. All equations for calculating the solar radiation incident are attached in Appendix A.

\subsection{Effective Efficiency Calculation}

To evaluate the economic performance, the effective efficiency of the solar air heater is estimated according to the Equation (2) [31].

$$
m \eta_{e f f}=\frac{Q_{u}-\frac{P_{m}}{C}}{I_{T} A_{C}}
$$

where, 
$\eta_{\text {eff }} \quad$ Effective efficiency of the solar air heater (\%)

$Q_{u} \quad$ Useful thermal energy gained by the solar air heater (W)

$P_{m} \quad$ Mechanical power that required to force the air through the solar air collector $(\mathrm{W})$

$C$ the conversion factor

$I_{T} \quad$ Solar radiation on the tilted solar air heater surface $\left(\mathrm{W} / \mathrm{m}^{2}\right)$

$A_{c} \quad$ Solar air heater effective area $\left(\mathrm{m}^{2}\right)$

The conversion factor $(C)$ is the energy conversion efficiency from the primary energy to the mechanical energy, and a typical value of 0.18 is suggested to be considered [31,32].

The required mechanical power $\left(P_{m}\right)$ can be estimated according to the Equation (3).

$$
P_{m}=Q \Delta P=\vartheta A_{d} \Delta P
$$

where,

$P_{m} \quad$ Mechanical power that required to force the air through the solar air collector $(\mathrm{W})$

$Q \quad$ Volume flow rate $\left(\mathrm{m}^{3} / \mathrm{s}\right)$

$\Delta P \quad$ Pressure drop inside the air channel $\left(\mathrm{N} / \mathrm{m}^{2}\right)$

In this study, the pressure drops due to others have been discarded, while the pressure drops due to the air moves through the absorber layer and inside the air channel are estimated according to the Equation (4) [33].

$$
\Delta P=\frac{2 \rho f \vartheta^{2} L}{D_{h}}
$$

where,

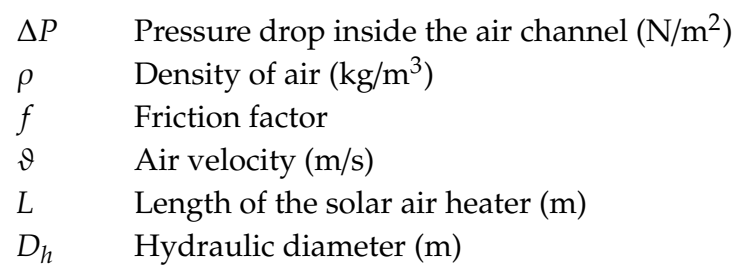

The fraction factor can be estimated according to the Equation (5) and Equation (6) [16].

$$
\begin{gathered}
\left.f=0.059 R_{e}^{-0.2} \text { (for turbulent flow }\right) \\
f=\frac{16}{R_{e}}(\text { for lamina flow })
\end{gathered}
$$

The hydraulic diameter of the air channel can be estimated according to the Equation (7).

$$
D_{h}=\frac{2 a b}{(a+b)}
$$

where,

$D_{h} \quad$ Hydraulic diameter $(\mathrm{m})$

$a \quad$ Width of the air channel (m)

$b \quad$ Depth of the air channel (m)

The hydraulic diameter of the absorber layer needs to multiply the porosity of the absorber layer. The porosity can be estimated according to the Equation (8).

$$
\varphi=\frac{\pi d_{H}^{2}}{4 d_{S^{2}}^{2}}
$$

where, 


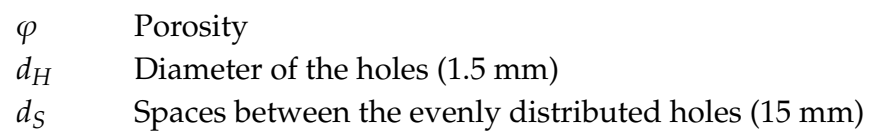

Reynolds number can be estimated according to Equation (9).

$$
R_{e}=\frac{\rho \vartheta D_{h}}{\mu}
$$

where,

$$
\begin{array}{ll}
R_{e} & \text { Reynolds number } \\
\mu & \text { Dynamic viscosity }\left(\mathrm{kg} /\left(\mathrm{m}^{*} \mathrm{~s}\right)\right)
\end{array}
$$

The dynamic viscosity of the air was set according to the air temperature, as shown in Table 3.

\subsection{The Uncertainty Calculation}

In this study, the errors from both the monitoring devices and the measurements have been analyzed [19]. The independent measurements include the inlet air temperature, the outlet air temperature, the outlet air velocity and the solar air radiation. The equipment used and the uncertainty of these equipment has shown in Equation (10). Considering the density of the air, the specific heat of the air as constant. The fractional uncertainty of the solar air heater thermal efficiency is estimated according to Equation (10).

$$
\frac{\omega_{\eta}}{\eta}=\sqrt{\left(\frac{\omega_{m}}{m}\right)^{2}+\left(\frac{\omega_{I}}{I}\right)^{2}+\left(\frac{\omega_{\Delta T}}{T_{o}-T_{i}}\right)^{2}}
$$

where,

$\omega_{x} \quad$ Uncertainty of the variable $\mathrm{x}$

The uncertainty of the variable $x$ can be estimated according to Equation (11).

$$
\omega_{x}=\sqrt{\sigma_{\bar{x}}^{2}+\Delta_{\text {instrument }}^{2}}
$$

where,

$\begin{array}{ll}\omega_{x} & \text { Uncertainty of the variable } \mathrm{x} \\ \sigma_{\bar{x}} & \text { Standard deviation of the variable } \mathrm{x} \\ \Delta_{\text {instrument }} & \text { Uncertainty of the instrument }\end{array}$

Results show that the mean values for all the days together for $\Delta \mathrm{T}, T_{i}, T_{0}, \dot{m}, I_{T}$, and the thermal efficiency are $17.6{ }^{\circ} \mathrm{C}, 19.1^{\circ} \mathrm{C}, 36.7^{\circ} \mathrm{C}, 0.032 \mathrm{~kg} / \mathrm{s}, 428 \mathrm{~W} / \mathrm{m}^{2}$, and $44 \%$ respectively. The fractional uncertainty of the efficiency is found to be 0.0061 . The theoretical prediction of this SAH was analyzed by McGowan [34]. This study focuses on the experimental results. All calculations were conducted using the statistical computing and graphics platform programming language R version 3.4.3 [35].

\section{Results and Discussion}

\subsection{Ambient Weather Conditions during Experiment}

During the test, the weather data was monitored at 1-min interval. It found that the solar radiation ranged from $104 \mathrm{~W} / \mathrm{m}^{2}$ (minimum) to $1298 \mathrm{~W} / \mathrm{m}^{2}$ (maximum), with the mean ( \pm standard deviation, SD) level of $544( \pm 270) \mathrm{W} / \mathrm{m}^{2}$. The ambient temperature ranged from $15.7^{\circ} \mathrm{C}$ (minimum) to $22.8^{\circ} \mathrm{C}$ (maximum), with the mean $( \pm \mathrm{SD})$ of $19.1 \pm 1.7^{\circ} \mathrm{C}$. The wind speed ranged from $0 \mathrm{~m} / \mathrm{s}$ to $9.6 \mathrm{~m} / \mathrm{s}$, with the mean $( \pm \mathrm{SD}$ ) level of $2.0 \pm 1.3 \mathrm{~m} / \mathrm{s}$. For $99.3 \%$ of the time, the wind speed was between $0 \mathrm{~m} / \mathrm{s}$ and $6.0 \mathrm{~m} / \mathrm{s}, 0.7 \%$ of the monitored wind speed was above $6.0 \mathrm{~m} / \mathrm{s}$. 
Figure 4 shows the hourly global horizontal solar radiation (top), ambient temperature (middle) and wind speed (bottom) on each test day.

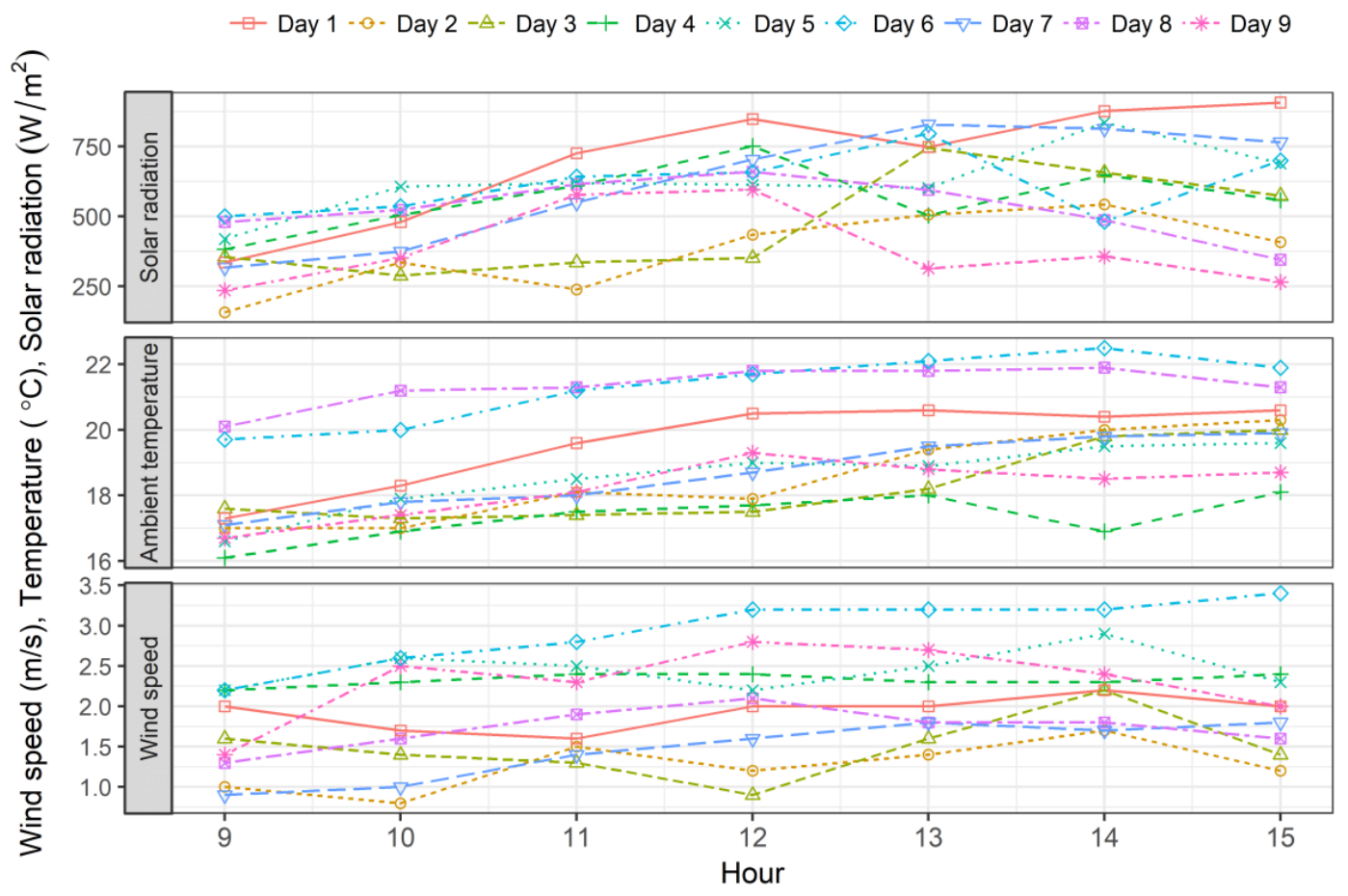

Figure 4. Hourly levels of the global horizontal solar radiation, ambient temperature and wind speed on each test day.

The hourly solar radiation ranged from $157 \mathrm{~W} / \mathrm{m}^{2}$ (minimum) to $908 \mathrm{~W} / \mathrm{m}^{2}$ (maximum). The hourly ambient temperature was from $16.1{ }^{\circ} \mathrm{C}$ to $22.5{ }^{\circ} \mathrm{C}$. The hourly wind speed was between $0.8 \mathrm{~m} / \mathrm{s}$ to $3.4 \mathrm{~m} / \mathrm{s}$. The mean $( \pm \mathrm{SD})$ values of the global horizontal solar radiation, ambient temperature and wind speed on each test day are shown in Table 4.

Table 4. Mean ( \pm standard deviation) values of the global horizontal solar radiation, ambient temperature and wind speed on each test day.

\begin{tabular}{cccc}
\hline Test Day & Solar Radiation $\left(\mathbf{W} / \mathbf{m}^{\mathbf{2}}\right)$ & Ambient Temperature $\left({ }^{\circ} \mathbf{C}\right)$ & Wind Speed $(\mathbf{m} / \mathbf{s})$ \\
\hline Day 1 & $703.3 \pm 286.6$ & $19.6 \pm 1.3$ & $1.9 \pm 1.1$ \\
Day 2 & $374.8 \pm 161.6$ & $18.5 \pm 1.3$ & $1.3 \pm 1.0$ \\
Day 3 & $473.6 \pm 255.8$ & $18.3 \pm 1.1$ & $1.5 \pm 1.1$ \\
Day 4 & $566.7 \pm 277.9$ & $17.3 \pm 0.8$ & $2.3 \pm 1.3$ \\
Day 5 & $626.5 \pm 299.2$ & $18.6 \pm 1.0$ & $2.5 \pm 1.4$ \\
Day 6 & $616.5 \pm 252.2$ & $21.3 \pm 1.0$ & $3.0 \pm 1.5$ \\
Day 7 & $622.0 \pm 314.3$ & $18.7 \pm 1.0$ & $1.5 \pm 1.0$ \\
Day 8 & $529.6 \pm 152.8$ & $21.3 \pm 0.6$ & $1.7 \pm 1.0$ \\
Day 9 & $385.3 \pm 180.3$ & $18.2 \pm 0.9$ & $2.3 \pm 1.3$ \\
\hline
\end{tabular}

The highest and the lowest mean global horizontal solar radiation during the test days was 703.3 $\pm 286.6 \mathrm{~W} / \mathrm{m}^{2}$ (Day 1) and $374.8 \pm 161.6 \mathrm{~W} / \mathrm{m}^{2}$ (Day 2) respectively. The mean ambient temperature ranged from $17.3 \pm 0.8^{\circ} \mathrm{C}$ (Day 4) to $21.3 \pm 1.0^{\circ} \mathrm{C}$ (Day 6). The highest and lowest mean wind speed was $3.0 \pm 1.5 \mathrm{~m} / \mathrm{s}$ (Day 6), and $1.3 \pm 1.0 \mathrm{~m} / \mathrm{s}$ (Day 2) respectively. 


\subsection{Outlet Air Temperature of the Studied SAH}

The air mass flow rate affects the outlet air temperature. A higher air mass flow rate makes the less time for air circulating inside the air channel and absorbing the heat. Consequently, it results in a lower outlet air temperature [36]. During the test, the air mass flow rate was between $0.022 \pm 0.001 \mathrm{~kg} / \mathrm{s}$ and $0.056 \pm 0.005 \mathrm{~kg} / \mathrm{s}$. Table 5 shows mean $( \pm \mathrm{SD})$ values of the outlet air velocity $(\mathrm{m} / \mathrm{s})$, air mass flow rate $(\mathrm{kg} / \mathrm{s})$, solar radiation on the $\mathrm{SAH}$ collector surface $\left(\mathrm{W} / \mathrm{m}^{2}\right)$, the outlet air temperature $\left({ }^{\circ} \mathrm{C}\right)$, and the temperature difference between the outlet air and the inlet air $\left(\Delta T, T_{\text {outlet }}-T_{\text {inlet }}\right)$ on each test day.

Table 5. The mean and standard deviation (SD) of the velocity, air mass flow rate, solar radiation on the collector surface, outlet air temperature, and the temperature difference between the outlet air and the inlet air of the SAH on each test day.

\begin{tabular}{|c|c|c|c|c|c|c|}
\hline $\begin{array}{l}\text { Percent of Maximum } \\
\text { Speed of the Ventilator } \\
(\%)\end{array}$ & Test Day & $\begin{array}{l}\text { Velocity } \\
(\mathrm{m} / \mathrm{s})\end{array}$ & $\begin{array}{l}\text { Air Mass Flow Rate } \\
\qquad\left(\mathrm{kg}^{*} \mathrm{~s}^{-1}\right)\end{array}$ & $I_{T}{ }^{1}\left(\mathrm{~W} / \mathrm{m}^{2}\right)$ & $\begin{array}{c}\mathrm{T}^{2} \text { Outlet Air } \\
\left({ }^{\circ} \mathrm{C}\right)\end{array}$ & $\begin{array}{c}\text { T Difference }{ }^{3} \\
\left({ }^{\circ} \mathrm{C}\right)\end{array}$ \\
\hline \multirow[t]{4}{*}{$50 \%$} & Day 1 & $1.5 \pm 0.1$ & $0.014 \pm 0.006$ & $552 \pm 178$ & $45.2 \pm 9.3$ & $25.5 \pm 8.3$ \\
\hline & Day 2 & $1.5 \pm 0.1$ & $0.021 \pm 0.001$ & $297 \pm 113$ & $31.6 \pm 6.4$ & $13.1 \pm 5.6$ \\
\hline & Day 3 & $1.6 \pm 0.1$ & $0.021 \pm 0.004$ & $376 \pm 153$ & $34.6 \pm 8.3$ & $16.3 \pm 7.8$ \\
\hline & Day 4 & $1.7 \pm 0.1$ & $0.019 \pm 0.006$ & $451 \pm 106$ & $39.5 \pm 8.9$ & $22.2 \pm 8.7$ \\
\hline \multirow[t]{4}{*}{$75 \%$} & Day 5 & $2.6 \pm 0.1$ & $0.034 \pm 0.005$ & $490 \pm 112$ & $37.1 \pm 6.1$ & $18.6 \pm 5.7$ \\
\hline & Day 6 & $2.7 \pm 0.1$ & $0.035 \pm 0.004$ & $478 \pm 111$ & $39.1 \pm 5.5$ & $17.8 \pm 5.3$ \\
\hline & Day 7 & $2.7 \pm 0.1$ & $0.036 \pm 0.005$ & $494 \pm 175$ & $36.9 \pm 8.9$ & $18.3 \pm 8.3$ \\
\hline & Day 8 & $2.7 \pm 0.1$ & $0.036 \pm 0.002$ & $414 \pm 92$ & $36.9 \pm 5.0$ & $15.5 \pm 4.9$ \\
\hline $100 \%$ & Day 9 & $4.0 \pm 0.1$ & $0.056 \pm 0.005$ & $304 \pm 117$ & $29.7 \pm 6.3$ & $11.5 \pm 5.9$ \\
\hline
\end{tabular}

${ }^{1}$ Solar radiation on the collector surface $\left(\mathrm{W} / \mathrm{m}^{2}\right) .{ }^{2}$ Temperature of the outlet air. ${ }^{3}$ Temperature difference between the outlet air and the inlet air, $\Delta \mathrm{T}\left(\mathrm{T}_{\text {outlet }}-\mathrm{T}_{\text {inlet }}\right)$.

The outlet air temperature ranged from $19.9{ }^{\circ} \mathrm{C}$ to $59.8^{\circ} \mathrm{C}$, with the mean level of $36.7^{\circ} \mathrm{C}$ (SD: $\left.8.5^{\circ} \mathrm{C}\right)$. Table 5 shows the mean $\left( \pm \mathrm{SD}\right.$ ) values of the outlet air temperature ranged from $29.7 \pm 6.3^{\circ} \mathrm{C}$ (Day 9) to $45.2 \pm 9.3^{\circ} \mathrm{C}$ (Day 1). The mean level of the solar radiation on Day 1 was higher than on the other days that had the same setting of the fan speed controller (Day 2 to Day 4, 50\% maximum speed of the ventilator). This resulted in the mean outlet air temperature on Day 1 higher than on Day 2 to Day 4. Consequently, the air density and the mass flow rate on Day 1 were lower than on Day 2, Day 3 and Day 4 regardless of the similar air velocity. The mean air mass flow rate on Day 5 to Day 8 was between $0.032 \mathrm{~kg} / \mathrm{s}$ and $0.038 \mathrm{~kg} / \mathrm{s}$, at $75 \%$ maximum speed of the ventilator. The mean ( \pm SD) value of mass flow rate on Day 9 was $0.056 \pm 0.005 \mathrm{~kg} / \mathrm{s}$. The fieldwork performance of this SAH when it was roof-mounted on the NZ primary schools in winter has been reported $[37,38]$.

Levels of $\Delta \mathrm{T}\left(\mathrm{T}_{\text {outlet }}-\mathrm{T}_{\text {inlet }}\right)$ obtained during the experiment was from $3.2{ }^{\circ} \mathrm{C}$ (minimum) to $41.0^{\circ} \mathrm{C}$ (maximum). The mean $( \pm \mathrm{SD})$ values of $\Delta \mathrm{T}\left(\mathrm{T}_{\text {outlet }}-\mathrm{T}_{\text {inlet }}\right)$ ranged from $11.5 \pm 5.9^{\circ} \mathrm{C}$ (Day 9) to 25.5 $\pm 8.3^{\circ} \mathrm{C}$ (Day 1). The maximum $\Delta \mathrm{T}\left(\mathrm{T}_{\text {outlet }}-\mathrm{T}_{\text {inlet }}\right)$ was $41.0^{\circ} \mathrm{C}$. This was obtained on Day 4 noon when the wind speed was $2.2 \mathrm{~m} / \mathrm{s}$, the inlet air temperature was $17.5^{\circ} \mathrm{C}$, and the solar radiation was $901 \mathrm{~W} / \mathrm{m}^{2}$. Multiple linear regressions were built to investigate the attribute of the $\Delta \mathrm{T}\left(\mathrm{T}_{\text {outlet }}-\mathrm{T}_{\text {inlet }}\right)$, when it was operated at different air mass flow rate. The model input variables include the solar radiation, air mass flow rate, inlet air temperature and the wind speed.

As expected, a positive relationship between $\Delta \mathrm{T}\left(\mathrm{T}_{\text {outlet }}-\mathrm{T}_{\text {inlet }}\right)$ and the solar radiation, a negative relationship between $\Delta \mathrm{T}\left(\mathrm{T}_{\text {outlet }}-\mathrm{T}_{\text {inlet }}\right)$ and the air mass flow rate were observed in this study. When the SAH was operated at air mass flow rate between 0.021 and $0.023 \mathrm{~kg} / \mathrm{s}, \Delta \mathrm{T}\left(\mathrm{T}_{\text {outlet }}-\mathrm{T}_{\text {inlet }}\right)$ was impacted by the solar radiation and mass flow rate. When the SAH was operated at flow rate between 0.032 and $0.038 \mathrm{~kg} / \mathrm{s}$, the solar radiation, the mass flow rate, the wind speed and the inlet air temperature all affected the $\Delta \mathrm{T}\left(\mathrm{T}_{\text {outlet }}-\mathrm{T}_{\text {inlet }}\right)$. When this SAH was operated at flow rate between 0.054 and $0.058 \mathrm{~kg} / \mathrm{s}$, only the solar radiation levels affected the $\Delta \mathrm{T}\left(\mathrm{T}_{\text {outlet }}-\mathrm{T}_{\text {inlet }}\right)$ levels. This result was supported by Omojaro and Aldabbagh [19] and Aldabbagh, Egelioglu and Ilkan [22], where there were a negative relationship between $\Delta \mathrm{T}\left(\mathrm{T}_{\text {outlet }}-\mathrm{T}_{\text {inlet }}\right)$ and the air mass flow rate, and a positive relationship between $\Delta \mathrm{T}\left(\mathrm{T}_{\text {outlet }}-\mathrm{T}_{\text {inlet }}\right)$ and the solar radiation. 


\subsection{Thermal Efficiency and Effective Efficiency of the Studied Solar Air Heater}

Figure 5 shows the efficiency versus values of the efficiency function parameter $\left(\Delta \mathrm{T}\left(\mathrm{T}_{\text {outlet }}-\mathrm{T}_{\text {inlet }}\right) / I_{T}\right)$ at different air mass flow rate. The regression models for efficiencies of the SAH under different mass flow rate have been added.

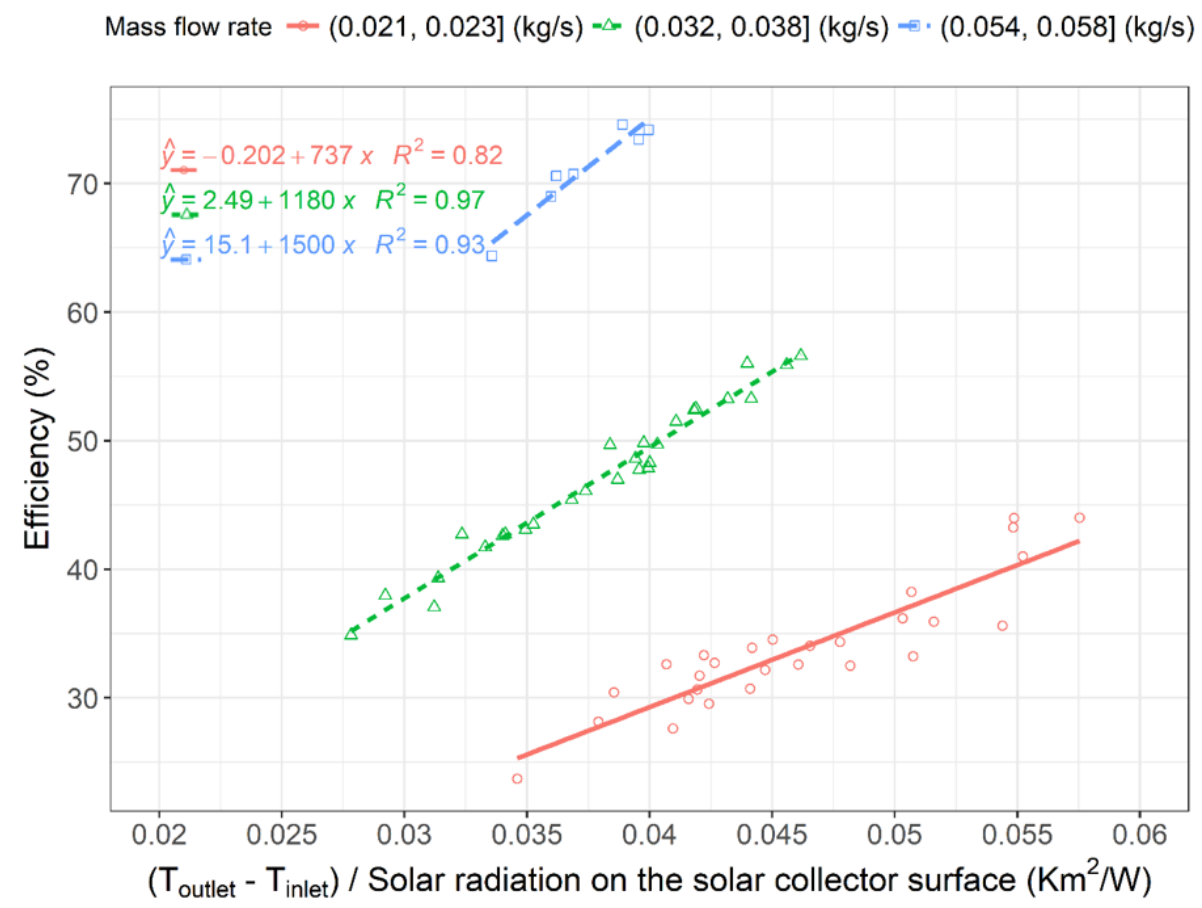

Figure 5. Efficiency of the solar air heater versus the value of the efficiency function at different air mass flow rate. The efficiency function is the temperature difference between outlet air $\left(\mathrm{T}_{\text {outlet }}\right)$, and inlet air $\left(\mathrm{T}_{\text {inlet }}\right)$ divide the solar radiation on the collector panel $\left(\mathrm{I}_{\mathrm{T}}\right)$.

Figure 5 shows that during the experiment, the $\Delta \mathrm{T}\left(\mathrm{T}_{\text {outlet }}-\mathrm{T}_{\text {inlet }}\right) / I_{T}$ was between 0.027 and $0.058 \mathrm{Km}^{2} / \mathrm{W}$. From the regression model, it can be estimated that, when the value of $\left(\mathrm{T}_{\text {outlet }}-\mathrm{T}_{\text {inlet }}\right) / I_{T}$ is ca. $0.04 \mathrm{Km}^{2} / \mathrm{W}$, the efficiency of the SAH was ca. $29 \%, 50 \%$ and $75 \%$ at an air mass flow rate of ca. $0.022 \mathrm{~kg} / \mathrm{s}, 0.037 \mathrm{~kg} / \mathrm{s}$ and $0.056 \mathrm{~kg} / \mathrm{s}$ respectively. This difference of the efficiency is getting bigger when the value of $\Delta \mathrm{T}\left(\mathrm{T}_{\text {outlet }}-\mathrm{T}_{\text {inlet }}\right) / I_{T}$ is increasing. This means the higher the air mass flow rate is, the more heat was transferred into the air.

Figure 6 shows the efficiency versus values of the efficiency function parameter $\left(\Delta \mathrm{T}\left(\mathrm{T}_{\text {outlet }}-\mathrm{T}_{\text {inlet }}\right) / I_{T}\right)$ at different air mass flow rate. The solid line is the thermal efficiency, and the dashed line is the effective efficiency.

Figure 6 shows that although the thermal efficiency increased with the increasing of the air mass flow rate, when considering the mechanic power consumed by the fan, the mean effective efficiency only had a $4 \%$ increase when the operated air mass flow rate increased from the range between $0.032 \mathrm{~kg} / \mathrm{s}$ and $0.038 \mathrm{~kg} / \mathrm{s}$ to $0.057 \mathrm{~kg} / \mathrm{s}$. The effective efficiency of the $\mathrm{SAH}$ was $32 \pm 5 \%$ at the airflow between $0.021 \mathrm{~kg} / \mathrm{s}$ and $0.023 \mathrm{~kg} / \mathrm{s}$, to $42 \pm 6 \%$ at the airflow ranging from $0.032 \mathrm{~kg} / \mathrm{s}$ to $0.038 \mathrm{~kg} / \mathrm{s}$, and $46 \pm 11 \%$ at the airflow of $0.056 \pm 0.005 \mathrm{~kg} / \mathrm{s}$. 


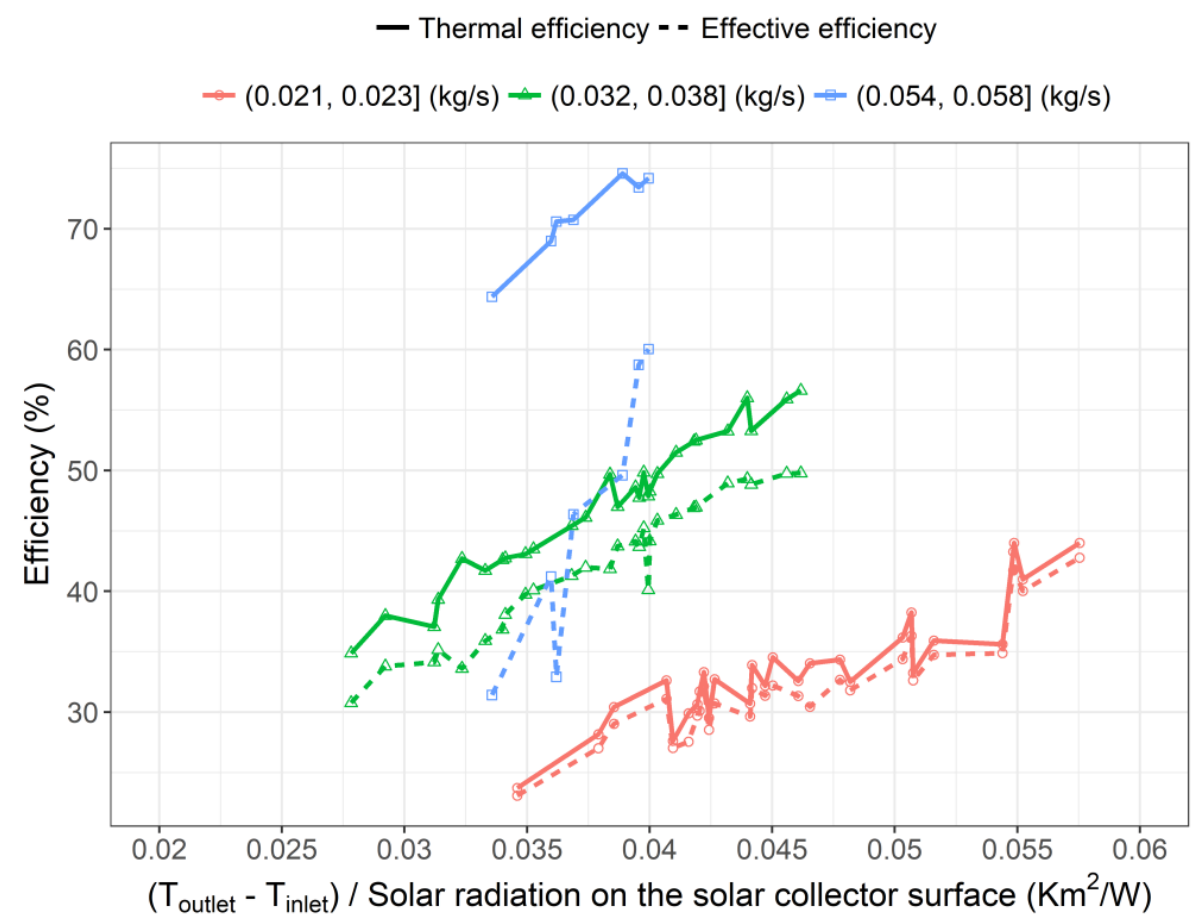

Figure 6. Thermal efficiency and effective efficiency of the solar air heater versus the value of the efficiency function at different air mass flow rate. The efficiency function is the temperature difference between outlet air $\left(\mathrm{T}_{\text {outlet }}\right)$, and inlet air $\left(\mathrm{T}_{\text {inlet }}\right)$ divide the solar radiation on the collector panel $\left(\mathrm{I}_{\mathrm{T}}\right)$.

\subsection{Discussions}

The efficiency of the studied SAH was $71 \pm 4 \%$ [min: $64 \%$, max: $75 \%$ ], at an air mass flow rate of $0.056 \pm 0.004 \mathrm{~kg} / \mathrm{s}$. The maximum thermal efficiency of $75 \%$ was found at the mass flow rate of $0.057 \mathrm{~kg} / \mathrm{s}$. Karim and Hawlader [17] reported a double pass V-corrugated SAH with maximum efficiency of $82 \%$ at an air mass flow rate of $0.056 \mathrm{~kg} / \mathrm{s}$. The maximum efficiency of $80 \%$ was found from a SAH with porous material between the absorber layer and bottom plate, when it was operated at air mass flow rate of $0.070 \mathrm{~kg} / \mathrm{s} \mathrm{[2].} \mathrm{Ozgen,} \mathrm{Esen} \mathrm{and} \mathrm{Esen} \mathrm{[18]} \mathrm{found} \mathrm{the} \mathrm{maximum} \mathrm{thermal} \mathrm{efficiency} \mathrm{of} \mathrm{a}$ double parallel flow SAH with aluminium absorber plate with zag-zig arranged aluminium cans on both side was $73 \%$ at an air mass flow rate of $0.055 \mathrm{~kg} / \mathrm{s}$. El-Sebaii, Aboul-Enein, Ramadan, Shalaby and Moharram [16] found the thermal efficiency of a double parallel pass V-corrugated SAH was 67\% at an air mass flow rate of $0.060 \mathrm{~kg} / \mathrm{s}$; the thermal efficiency of a double parallel flat SAH was $59 \%$ at an air mass flow rate of $0.060 \mathrm{~kg} / \mathrm{s}$.

At an air mass flow rate between $0.032 \mathrm{~kg} / \mathrm{s}$ and $0.038 \mathrm{~kg} / \mathrm{s}$, the efficiency of the SAH found in this study was $47 \pm 6 \%$ [min: 35\%, max: 57\%]. Prasad, et al. [39] found a single pass SAH with packed bed formed by wire mesh had the maximum efficiency of $59 \%$ at the mass flow rate of $0.035 \mathrm{~kg} / \mathrm{s}$. Omojaro and Aldabbagh [19] found the efficiency of a SAH with steel wire mesh was $60 \%$ (single pass SAH) and $64 \%$ (double pass SAH) when it was operated at mass flow rate of $0.038 \mathrm{~kg} / \mathrm{s}$. El-Sebaii, Aboul-Enein, Ramadan, Shalaby and Moharram [15] found a double parallel SAH had the thermal efficiency of $56 \%$ (flat absorber plate) and 65\% (V-corrugated absorber plate) when they were operated at mass flow rate of $0.040 \mathrm{~kg} / \mathrm{s}$.

At an air mass flow rate between 0.021 and $0.023 \mathrm{~kg} / \mathrm{s}$, the thermal efficiency of this studied SAH was $34 \pm 5 \%$ [min: 24\%, max: 44\%]. Chabane, Moummi and Benramache [9] reported the thermal efficiency of a SAH both with the longitudinal fins installed under the absorber layer and without the fins installed. It reported that the thermal efficiency of this SAH without fins was $35 \%$ and $44 \%$ at the air mass flow rate of $0.012 \mathrm{~kg} / \mathrm{s}$ and $0.016 \mathrm{~kg} / \mathrm{s}$ respectively. This thermal efficiency was increased to $40 \%$ and $52 \%$ for the SAH with the fins [9]. 
Overall, the efficiency of this studied SAH was higher than the efficiency of some SAHs reported in literature, when it was operated at air mass flow rate of $0.057 \mathrm{~kg} / \mathrm{s}(100 \%$ maximum ventilator). However, when this studied SAH was operated at $50 \%$ and $75 \%$ of maximum ventilators, its efficiency was lower than efficiency of some SAHs reported in literature.

\section{Conclusions}

This paper has investigated the experimental performance of a SAH under Auckland (NZ) weather conditions. This SAH has the inlet air passing through a perforated back plate and the felt absorber layer. This study found when the SAH was operated at 100\% maximum fan speed (mass flow rate range from $0.054 \mathrm{~kg} / \mathrm{s}$ to $0.058 \mathrm{~kg} / \mathrm{s}$ ), the wind speed and the inlet air temperature did not impact the $\Delta \mathrm{T}\left(\mathrm{T}_{\text {outlet }}-\mathrm{T}_{\text {inlet }}\right)$ and thermal efficiency. The maximum $\Delta \mathrm{T}\left(\mathrm{T}_{\text {outlet }}-\mathrm{T}_{\text {inlet }}\right)$ of $41^{\circ} \mathrm{C}$ was obtained at the wind speed $2.2 \mathrm{~m} / \mathrm{s}$, the inlet air temperature was $17.5^{\circ} \mathrm{C}$ and the solar radiation was $901 \mathrm{~W} / \mathrm{m}^{2}$, when the SAH was operated at the mass flow rate of $0.022 \mathrm{~kg} / \mathrm{s}$. The maximum thermal efficiency of $75 \%$ was achieved when it was operated at air mass flow rate $0.057 \mathrm{~kg} / \mathrm{s}$.

Compared with the thermal efficiency of other solar air heaters that have been reported in the literature, this studied solar air heater has a higher thermal efficiency when it was operated at the air mass flow rate of $0.057 \mathrm{~kg} / \mathrm{s}$, but has a lower thermal efficiency when it was operated at the air mass flow rate between $0.032 \mathrm{~kg} / \mathrm{s}$ and $0.038 \mathrm{~kg} / \mathrm{s}$. However, when considering the economic performance, the mean effective efficiency had a $4 \%$ increase when the operated air mass flow rate increased from the range between $0.032 \mathrm{~kg} / \mathrm{s}$ and $0.038 \mathrm{~kg} / \mathrm{s}$ to $0.057 \mathrm{~kg} / \mathrm{s}$. Future studies could confirm the optimum operational conditions by combining the theoretical analysis and experimental data. With the results of the theoretical analysis, future modifications of this SAH, i.e., moving the outlet air duct to a central location, increasing the diameter of the holes on the perforated back plate, and change the current downward type outlet air duct to an upward type, could be needed to enhance the heat transfer of the solar air heater.

Author Contributions: Y.W., M.B. and R.P. conceived and designed the experiments; M.B., R.P., M.P. and Chris Cunningham substantively revised the paper; Y.W. performed the experiment, analyzed the data and wrote the paper. All authors have read and agreed to the published version of the manuscript.

Funding: This research was funded by Health Research Council of New Zealand, grant number 12/664" and "The APC was funded by Building Performance Research Group, School of Built Environment, Massey University".

Acknowledgments: This work was supported by Health Research Council of New Zealand and Lottery Health Research Grant. The authors would like to thank Building Research Association of New Zealand for their technical and equipment support. Authors are grateful for the technical support from Eamon Corless (Solair Pty Ltd.) and Hans Joergen Christensen (SolarVenti). Authors would like to thank Chris Chitty for helping designing, fabricating and installing the test rig. Special thanks to staff from Massey University Facilities Management and Simply Security Ltd. for moving the testing rig between the test site and the overnight storage room.

Conflicts of Interest: The authors declare no conflict of interest.

\section{Appendix A}

Spencer model to estimate the declination angle:

$$
\begin{gathered}
\delta=(180 / \pi)(0.006918-0.366612 \cos B+0.070257 \sin B-0.006758 \cos 2 B \\
+0.000907 \sin 2 B-0.002697 \cos 3 B+0.00148 \sin 3 B) \\
B=(n-1) \frac{360}{365}
\end{gathered}
$$

where

$\delta \quad$ the declination angle

$n \quad$ the nth day of the year 
Spencer model to calculate the extra-terrestrial radiation incident on the plane:

$$
\begin{gathered}
G_{o n}=G_{S C}(1.000110+0.034221 \cos B+0.001280 \sin B+0.000719 \cos 2 B \\
+0.000077 \sin 2 B) \\
G_{S C}=1366.1 \mathrm{~W} / \mathrm{m}^{2}
\end{gathered}
$$

where

$G_{o n}$ the extra-terrestrial radiation incident on the plane

$G_{S C}$ the solar constant

Boland-Ridley-Lauret (BRL) model to estimate the horizontal diffuse solar radiation from the global horizontal solar radiation.

$$
\begin{gathered}
d=\frac{I_{\text {diffuse }}}{I_{\text {global }}}=\frac{1}{1+e^{-5.38+6.63 k_{t}+0.006 A S T+0.007 \alpha+1.75 K_{t}+1.31 \psi}} \\
k_{t}=\frac{I_{\text {global }}}{H_{0}} \\
K_{t}=\frac{\sum_{j=1}^{24} I_{\text {global }_{j}}}{\sum_{j=1}^{24} H_{0_{j}}} \\
\psi=\left\{\begin{array}{r}
\frac{k_{t-1}+k_{t+1}}{2}, \text { sunrise }<t<\text { sunset } \\
k_{t+1}, t=\text { sunrise } \\
k_{t-1}, t=\text { sunset }
\end{array}\right.
\end{gathered}
$$

where

d Diffuse fraction

$I_{\text {diffuse }}$ Hourly horizontal diffuse solar radiation

$I_{\text {global }}$ Hourly horizontal global solar radiation

$k_{t} \quad$ Hourly clearness index

AST Apparent solar time

$\alpha \quad$ Solar angle in degrees

$K_{t} \quad$ Daily clearness index

$\psi \quad$ Error or residual values

$H_{0} \quad$ Hourly extraterrestrial radiation

Hay and McKay model to estimate the solar irradiance on the tilted panel.

$$
D_{s}=D\left[\frac{I}{I_{0}} * \frac{\cos i}{\cos z}+0.5\left(1-\frac{I}{I_{0}}\right)(1+\cos \rho)\right]
$$

where

$D_{s} \quad$ Diffuse solar irradiance for an inclined surface

$D \quad$ Diffuse sky irradiance

I Radiant intensity at normal incidence

$I_{0} \quad$ Solar constant

$i \quad$ Angle of incidence between Sun and normal to the surface

$z \quad$ Solar zenith angle

$\beta \quad$ Panel tilted angle (slope angle)

\section{References}

1. Esen, H.; Ozgen, F.; Esen, M.; Sengur, A. Modelling of a new solar air heater through least-squares support vector machines. Expert Syst. Appl. 2009, 36, 10673-10682. [CrossRef] 
2. Sopian, K.; Supranto; Daud, W.R.W.; Othman, M.Y.; Yatim, B. Thermal performance of the double-pass solar collector with and without porous media. Renew. Energy 1999, 18, 557-564. [CrossRef]

3. Akpinar, E.K.; Koçyiğit, F. Energy and exergy analysis of a new flat-plate solar air heater having different obstacles on absorber plates. Appl. Energy 2010, 87, 3438-3450. [CrossRef]

4. Promvonge, P.; Khanoknaiyakarn, C.; Kwankaomeng, S.; Thianpong, C. Thermal behavior in solar air heater channel fitted with combined rib and delta-winglet. Int. Commun. Heat Mass Transf. 2011, 38, 749-756. [CrossRef]

5. El-Sebaii, A.A.; Aboul-Enein, S.; Ramadan, M.R.I.; El-Bialy, E. Year round performance of double pass solar air heater with packed bed. Energy Convers. Manag. 2007, 48, 990-1003. [CrossRef]

6. Jaurker, A.R.; Saini, J.S.; Gandhi, B.K. Heat transfer and friction characteristics of rectangular solar air heater duct using rib-grooved artificial roughness. Solar Energy 2006, 80, 895-907. [CrossRef]

7. Skullong, S.; Kwankaomeng, S.; Thianpong, C.; Promvonge, P. Thermal performance of turbulent flow in a solar air heater channel with rib-groove turbulators. Int. Commun. Heat Mass Transf. 2014, 50, $34-43$. [CrossRef]

8. Naphon, P. On the performance and entropy generation of the double-pass solar air heater with longitudinal fins. Renew. Energy 2005, 30, 1345-1357. [CrossRef]

9. Chabane, F.; Moummi, N.; Benramache, S. Experimental study of heat transfer and thermal performance with longitudinal fins of solar air heater. J. Adv. Res. 2014, 5, 183-192. [CrossRef] [PubMed]

10. Bahrehmand, D.; Ameri, M.; Gholampour, M. Energy and exergy analysis of different solar air collector systems with forced convection. Renew. Energy 2015, 83, 1119-1130. [CrossRef]

11. Yang, M.; Yang, X.; Li, X.; Wang, Z.; Wang, P. Design and optimization of a solar air heater with offset strip fin absorber plate. Appl. Energy 2014, 113, 1349-1362. [CrossRef]

12. Dhiman, P.; Thakur, N.S.; Chauhan, S.R. Thermal and thermohydraulic performance of counter and parallel flow packed bed solar air heaters. Renew. Energy 2012, 46, 259-268. [CrossRef]

13. Hernández, A.L.; Quiñonez, J.E. Analytical models of thermal performance of solar air heaters of double-parallel flow and double-pass counter flow. Renew. Energy 2013, 55, 380-391. [CrossRef]

14. Yeh, H.M.; Lin, T.T. Efficiency improvement of flat-plate solar air heaters. Energy 1996, 21, 435-443. [CrossRef]

15. El-Sebaii, A.A.; Aboul-Enein, S.; Ramadan, M.R.I.; Shalaby, S.M.; Moharram, B.M. Thermal performance investigation of double pass-finned plate solar air heater. Appl. Energy 2011, 88, 1727-1739. [CrossRef]

16. El-Sebaii, A.A.; Aboul-Enein, S.; Ramadan, M.R.I.; Shalaby, S.M.; Moharram, B.M. Investigation of thermal performance of-double pass-flat and v-corrugated plate solar air heaters. Energy 2011, 36, 1076-1086. [CrossRef]

17. Karim, M.; Hawlader, M. Performance investigation of flat plate, v-corrugated and finned air collectors. Energy 2006, 31, 452-470. [CrossRef]

18. Ozgen, F.; Esen, M.; Esen, H. Experimental investigation of thermal performance of a double-flow solar air heater having aluminium cans. Renew. Energy 2009, 34, 2391-2398. [CrossRef]

19. Omojaro, A.P.; Aldabbagh, L.B.Y. Experimental performance of single and double pass solar air heater with fins and steel wire mesh as absorber. Appl. Energy 2010, 87, 3759-3765. [CrossRef]

20. El-khawajah, M.F.; Aldabbagh, L.B.Y.; Egelioglu, F. The effect of using transverse fins on a double pass flow solar air heater using wire mesh as an absorber. Solar Energy 2011, 85, 1479-1487. [CrossRef]

21. Esen, H. Experimental energy and exergy analysis of a double-flow solar air heater having different obstacles on absorber plates. Build. Environ. 2008, 43, 1046-1054. [CrossRef]

22. Aldabbagh, L.B.Y.; Egelioglu, F.; Ilkan, M. Single and double pass solar air heaters with wire mesh as packing bed. Energy 2010, 35, 3783-3787. [CrossRef]

23. Mahmood, A.J.; Aldabbagh, L.B.Y.; Egelioglu, F. Investigation of single and double pass solar air heater with transverse fins and a package wire mesh layer. Energy Convers. Manag. 2015, 89, 599-607. [CrossRef]

24. Nowzari, R.; Aldabbagh, L.B.Y.; Egelioglu, F. Single and double pass solar air heaters with partially perforated cover and packed mesh. Energy 2014, 73, 694-702. [CrossRef]

25. Cengel, Y.A. Thermodynamics: An Engineering Approach, 8th ed.; McGraw-Hill Education: New York, NY, USA, 2015; p. 996.

26. Lamigueiro, P.O. solaR: Solar Radiation and Photovoltaic Systems with R. J. Stat. Softw. 2012, 50, 1-32.

27. Spencer, J.W. Fourier Series Representation of the Position of the Sun. Search 1971, 2, 172. 
28. Ridley, B.; Boland, J.; Lauret, P. Modelling of diffuse solar fraction with multiple predictors. Renew. Energy 2010, 35, 478-483. [CrossRef]

29. Boland, J. Tools for Estimating Solar Radiation on Inclined Surfaces. Available online: http://www.lowcarbonlivingcrc.com.au/sites/all/files/event_file_attachments/session_2_-_estimating_ solar_radiation_prof_j_boland.pdf (accessed on 13 March 2016).

30. Hay, J.E.; McKay, D.C. Estimating Solar Irradiance on Inclined Surfaces: A Review and Assessment of Methodologies. Int. J. Solar Energy 1985, 3, 203. [CrossRef]

31. Cortés, A.; Piacentini, R. Improvement of the efficiency of a bare solar collector by means of turbulence promoters. Appl. Energy 1990, 36, 253-261. [CrossRef]

32. Mittal, M.K.; Varshney, L. Optimal thermohydraulic performance of a wire mesh packed solar air heater. Solar Energy 2006, 80, 1112-1120. [CrossRef]

33. Sopian, K.; Alghoul, M.A.; Alfegi, E.M.; Sulaiman, M.Y.; Musa, E.A. Evaluation of thermal efficiency of double-pass solar collector with porous-nonporous media. Renew. Energy 2009, 34, 640-645. [CrossRef]

34. McGowan, P. A Thermal Model for a Solar Ventilation System Used in NZ Schools. Master's Dissertation, Massey University, Auckland, New Zealand, 2016.

35. R Core Team. R: A Language and Environment for Statistical Computing. R Foundation for Statistical Computing; R Core Team: Vienna, Austria, 2016.

36. Tyagi, V.V.; Panwar, N.L.; Rahim, N.A.; Kothari, R. Review on solar air heating system with and without thermal energy storage system. Renew. Sustain. Energy Rev. 2012, 16, 2289-2303. [CrossRef]

37. Wang, Y.; Boulic, M.; Phipps, R.; Plagmann, M.; Cunningham, C.; Theobald, C.; Howden-Chapman, P.; Baker, M. Impacts of a solar ventilation unit on temperature and ventilation rate in New Zealand schools: An intervention study. In Proceedings of the 14th International Conference of Indoor Air Quality and Climate, Ghent, Belgium, 3-7 July 2016.

38. Boulic, M.; Wang, Y.; Phipps, R.; Plagmann, M.; Cunningham, C.; Theobald, C.; Howden-Chapman, P.; Baker, M. Increasing the ventilation rate and temperature in New Zealand classrooms using a solar roof collector. In Proceedings of the Central European towards Sustainable Building, Prague, Czech Repubic, 2-4 July 2019.

39. Prasad, S.B.; Saini, J.S.; Singh, K.M. Investigation of heat transfer and friction characteristics of packed bed solar air heater using wire mesh as packing material. Solar Energy 2009, 83, 773-783. [CrossRef]

(C) 2020 by the authors. Licensee MDPI, Basel, Switzerland. This article is an open access article distributed under the terms and conditions of the Creative Commons Attribution (CC BY) license (http://creativecommons.org/licenses/by/4.0/). 